\title{
Sama Sannipata Jwara- Sepsis, SIRS, MODS, Septic Shock and Delirium
}

\begin{abstract}
Jwara (fever) is considered as 'lord' among all diseases according to Ayurveda because of its power to afflict the body, mind and senses. Jwara may be a symptom of some other disease or can occur as an independent disease. Many types of jwara have been described in Ayurvedic classical texts. There are 13 types of sannipataja jwara (fever caused by the vitiation of all three doshas) among them 'Sama sannipata jwara (SSJ)' (where all the three doshas are equally dominant). The present article is based on SSJ, as till date there is no clear understanding about this condition and various confusions are prevailed on this topic. Previous works have compared SSJ with 'Stills disease' and 'Dengue fever' but the present study has a different view. The similarity between SSJ and 'sepsis/septic shock/systemic inflammatory response syndrome (SIRS)/multiple organ dysfunction syndrome (MODS)/septic encephalopathy/delirium' is explored in the present article. Karnamoola shotha which is the complication of sannipata jwara denotes a condition of mastoiditis leading to meningitis and death. There is profound similarity between SSJ and sepsis syndromes in terms of pathological progression, symptomatology and prognosis. Reference of the conditions like sepsis syndromes is described in Ayurvedic texts under the domain of Sannipata jwara many centuries before.
\end{abstract}

Keywords: Sannipata jwara; Ayurveda; Sepsis; Septic shock; SIRS; MODS; Delirium
Review Article

Volume 8 Issue 2 - 2017

Prasad Mamidi* and Kshama Gupta

Department of Kayachikitsa, Parul University, India

*Corresponding author: Prasad Mamidi, Associate Professor, Department of Kayachikitsa, Faculty of Ayurveda, Parul University, Vadodara, Gujarat, India 391760, Tel: 7567222856; Email: drprasadmamidi@gmail.com

Received: April 04, 2017 | Published: August 02, 2017

\section{Introduction}

Tridoshas (vata, pitta and kapha - the three basic functional factors of the body) are responsible to sustain the life in their homeostatic state according to Ayurveda. Vitiation of these tridoshas (the abnormal physiological state) is considered as pathology and no diseases can be occurred without the vitiation of vata, pitta and kapha either in singly (ekadoshaja), dually (dvidoshaja) or triply (sannipataja). Sannipata is a state in which quantitative/qualitative changes of tridoshas takes place but the degree of the involvement of each dosha may vary and the nomenclature is made accordingly based on the dominant dosha. Aggravation of tridosha at a same time or in consequence produces a complex phenomenon where the prognosis becomes worst. Sannipata, i.e. conglomeration of vitiated tridoshas is the final stage of manifestation of disease process. In sannipata state of pathogenesis the disease becomes more advance and mostly irreversible [1,2].

Jwara (fever) is considered as 'lord' among all diseases because of its power to afflict the body, mind and senses. Jwara frequently occurs at the time of birth and death of an individual [3]. Jwara may be a symptom of some other disease or can occur as independent disease. Jwara is characterized by Santaapa (elevated body temperature), Aruchi (loss of appetite), Trishna (excessive thirst), Angamarda (body aches), Hridivyatha (pain/ discomfort at left hypochondriac region) and Janmaadau nidhane (commonly seen at the time of birth and death of an individual) [4]. The vitiated doshas either alone or in combination along with ama (undigested food material/abnormal metabolites) and rasa dhatu (lymph) causes displacement of jatharagni (digestive fire) which manifests as jwara $[5,6]$.

Many types of jwara have been described in Ayurvedic classical texts i.e. brihat trayi (three major Ayurvedic classical texts - Charaka samhita, Sushruta samhita and Ashtanga hridaya) and laghu trayi (Madhava nidaana, Sharangadhara samhita and Bhava prakasha). According to causative factors jwara is divided in to two groups, nija (internal origin) and agantuja (external origin). Nija jwara occurs due to vitiated doshas, dhatus (tissue elements) etc; internal factors and agantuja occurs due to various factors which are external in origin like infections, injuries and also psychological factors like anger, depression, distress etc; Nija jwara is again classified in to ekadoshaja, dwidoshaja and sannipataja. There are 13 types of sannipataja jwara (fever caused by the vitiation of all three doshas). According to sharangadhara samhita, sannipata jwara is a single entity [7].

The present article is based on 'Sama sannipata jwara' (SSJ), as till date there is no clear understanding of this condition and various confusions are prevailed on this topic. Previous works have compared 'Sama annipata jwara' with 'Stills disease' [8] and 'Dengue fever' [9] but the present study has a different view. The present study aims at better understanding of SSJ and also to explore the similarities between 'SSJ' and 'Sepsis/Septic shock/ Systemic inflammatory response syndrome (SIRS)/multiple organ dysfunction syndrome (MODS)/Delirium'. 


\section{SSJ Lakshanas (Signs \& Symptoms)}

SSJ (in which all the three doshas are equally dominant) is one among 13 types of sannipata jwara. SSJ is characterized by, kshane daaha (fever), kshane sheeta (hypothermia), asthi sandhi ruja (arthralgia), shiro ruja (headache), saasrave kalushe rakte lochanam (conjunctivitis), sasvanau karnau (tinnitus), karna ruja (otalgia), kantha shookairiva (pharyngitis), tandra (fatigue), moha (confusion/loss of consciousness), pralaapa (irrelevant speech), kaasa (cough), shwaasa (dyspnea), aruchi (loss of appetite), bhrama (giddiness), paridagdha khara sparsha jihwa (dry, discoloration of tongue), srastaangata (malaise/weakness), kapha yukta rakta shteevanam (hemoptysis), shriaso lothanam (abnormal movements of the head or restlessness), nidra naasha (sleeplessness), hridivyatha, sweda mootra purisha chiraat darshanam (decreased sweating, decreased urine output and constipation), krushatwam naati gaatraanam (edema), kantha kujanam (abnormal respiratory sounds or stridor), shyaava rakta kotha (purpura/peripheral bleeding/cyanosis), mukatwam (loss of voice), srotasaam paaka (inflammation of various channels of the body), udara gurutwam (heaviness of abdomen) and chira paaka of doshas (slowly progressive/latent pathological process) [10]. There is profound similarity between SSJ lakshanas and sepsis, SIRS, MODS, septic shock and delirium (Table 1).

Table 1: Similarity between Sama sannipata jwara lakshanas and Sepsis syndromes.

\begin{tabular}{|c|c|}
\hline $\begin{array}{l}\text { Sama Sannipata Jwara } \\
\text { Lakshanas }\end{array}$ & $\begin{array}{c}\text { Sepsis/SIRS / MODS/Septic Shock/ } \\
\text { Delirium }\end{array}$ \\
\hline $\begin{array}{l}\text { Kshane daha \& Kshane } \\
\text { sheeta }\end{array}$ & $\begin{array}{c}\text { Fever \& Hypothermia; Temperature }> \\
38.5 \text { or }<35^{\circ} \mathrm{C}\end{array}$ \\
\hline Asthi sandhi ruja & Arthralgia, Myalgia \\
\hline Shiro ruja & $\begin{array}{l}\text { Headache (due to hypotension or upper/ } \\
\text { lower respiratory tract infection) }\end{array}$ \\
\hline $\begin{array}{l}\text { Saasraave kalushe rakte } \\
\text { lochane }\end{array}$ & Conjunctivitis \\
\hline $\begin{array}{l}\text { Saswanau karnau \& } \\
\text { Karna ruja }\end{array}$ & Otitis media \\
\hline Kantha shookairiva & Pharyngitis/Laryngitis \\
\hline Tandra & $\begin{array}{l}\text { Fatigue/Malaise (sepsis/acute } \\
\text { respiratory tract infection /hypotension) }\end{array}$ \\
\hline Moha & $\begin{array}{l}\text { Confusion/Loss of consciousness (septic } \\
\text { shock/ypotension/delirium) }\end{array}$ \\
\hline Pralaapa & Irrelevant speech (delirium?) \\
\hline Kaasa & $\begin{array}{c}\text { Cough (upper respiratory tract infection/ } \\
\text { pneumonia) }\end{array}$ \\
\hline
\end{tabular}

\begin{tabular}{|c|c|}
\hline Shwaasa & $\begin{array}{l}\text { Shortness of breath (tachypnea / } \\
\text { respiratory rate }>20 \text { breaths per } \\
\text { minute/Acute lung injury/Acute } \\
\text { respiratory distress syndrome) }\end{array}$ \\
\hline Aruchi & $\begin{array}{l}\text { Loss of appetite/Anorexia (respiratory } \\
\text { tract infection / sepsis) }\end{array}$ \\
\hline Bhrama & $\begin{array}{l}\text { Hypotension/reduction of cerebral blood } \\
\text { flow }\end{array}$ \\
\hline $\begin{array}{l}\text { Paridagdha, Khara } \\
\text { sparsha jihwa }\end{array}$ & $\begin{array}{l}\text { Dehydration (indicates need of fluid } \\
\text { resuscitation/septic shock) }\end{array}$ \\
\hline Srastaangata & $\begin{array}{l}\text { Malaise / weakness/fatigue (sepsis/ } \\
\text { respiratory infection) }\end{array}$ \\
\hline $\begin{array}{l}\text { Kapha yukta rakta } \\
\text { shteevanam }\end{array}$ & $\begin{array}{l}\text { Hemoptysis (respiratory infection/ } \\
\text { pneumonia) }\end{array}$ \\
\hline Shiraso lothanam & Restlessness/Septic encephalopathy \\
\hline Trishna & $\begin{array}{l}\text { Dehydration (septic shock/denotes } \\
\text { requirement of fluid resuscitation) }\end{array}$ \\
\hline Nidraa naasha & Restlessness/Sleeplessness (delirium) \\
\hline Hridi vyadha & Hypotension/Tachycardia/pericarditis \\
\hline $\begin{array}{l}\text { Chiraat and alpa sweda, } \\
\text { mutra and purisha }\end{array}$ & $\begin{array}{l}\text { Dehydration/Anuria/Oliguria/Acute } \\
\text { kidney injury/Constipation/MODS } \\
\text { (Multiple organ dysfunction syndrome)/ } \\
\text { septic shock }\end{array}$ \\
\hline $\begin{array}{l}\text { Krushatwam naati } \\
\text { gaatraanaam }\end{array}$ & $\begin{array}{c}\text { Odema (due to hypoperfusion of tissues/ } \\
\text { hepatic injury/cute kidney injury/ } \\
\text { hypoxemia) }\end{array}$ \\
\hline $\begin{array}{l}\text { Pratatam kantha } \\
\text { koojanam }\end{array}$ & $\begin{array}{l}\text { Tachypena/ARDS (Acute respiratory } \\
\text { distress syndrome) /ALI (Acute lung } \\
\text { injury) }\end{array}$ \\
\hline $\begin{array}{l}\text { Shyaava, Rakta kotha } \\
\text { and mandala }\end{array}$ & $\begin{array}{c}\text { Coagulopahty/Thrombocytopenia/ } \\
\text { Cyanosis }\end{array}$ \\
\hline Mookatwam & Loss of voice (due to laryngitis) \\
\hline Sroto paaka & $\begin{array}{l}\text { SIRS (Systemic inflammatory response } \\
\text { syndrome) }\end{array}$ \\
\hline Udara gauravam & $\begin{array}{l}\text { Hepatomegaly?/Edema in severe sepsis } \\
\text { due to capillary leak; }\end{array}$ \\
\hline $\begin{array}{l}\text { Chiraat paakashcha } \\
\text { doshaanaam }\end{array}$ & $\begin{array}{l}\text { Slowly progressive/latent pathological } \\
\text { process (indicates chronic/recurrent } \\
\text { infections in immuno-compromised } \\
\text { individuals leading to sepsis/septic } \\
\text { shock/delirium/death) }\end{array}$ \\
\hline Maranam & $\begin{array}{l}\text { Poor prognosis (MODS/delirium/septic } \\
\text { shock) }\end{array}$ \\
\hline $\begin{array}{l}\text { Upadrava - Karnamooa } \\
\text { shotha }\end{array}$ & $\begin{array}{l}\text { Mastoiditis leading to meningitis and } \\
\text { death }\end{array}$ \\
\hline
\end{tabular}




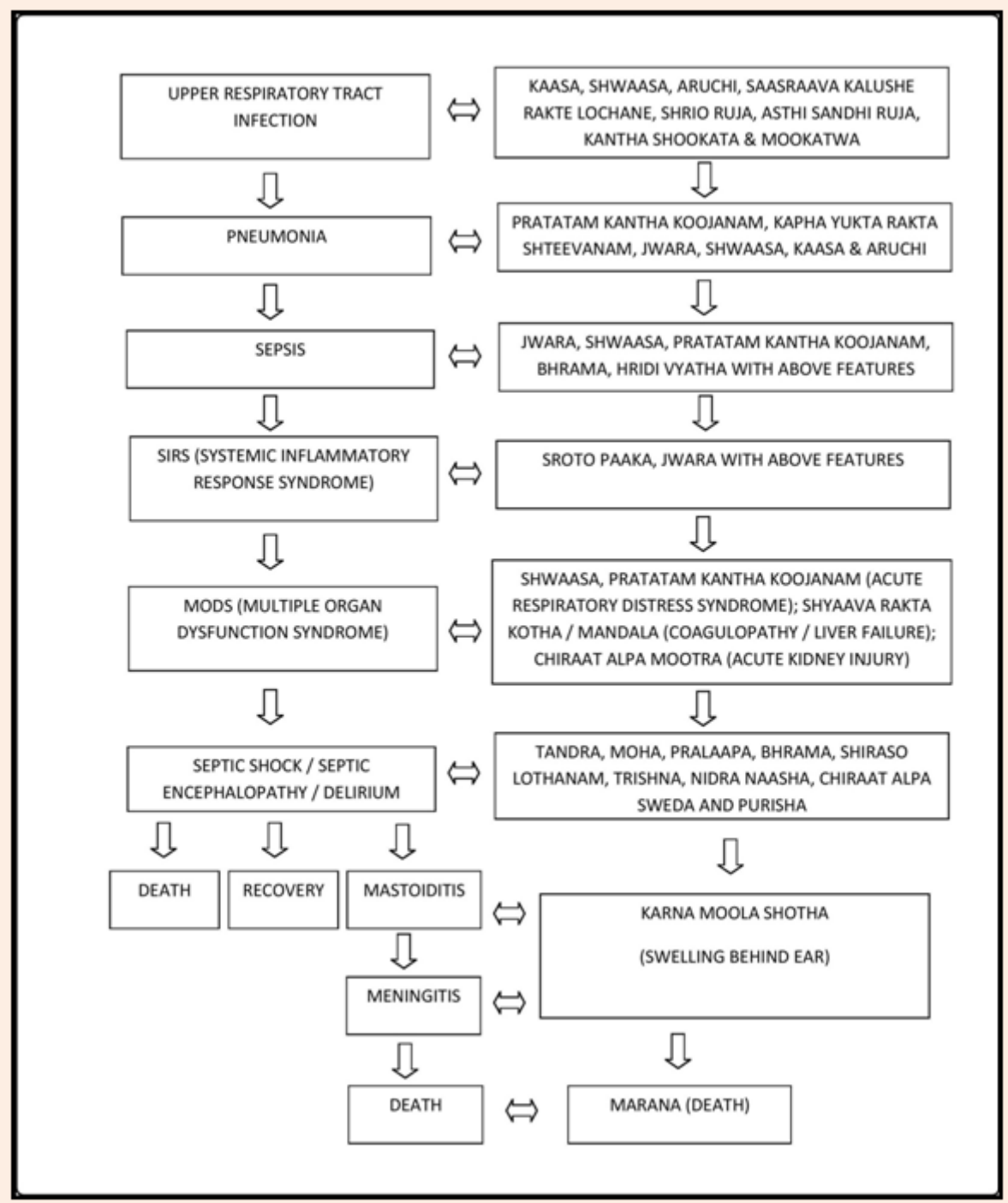

Figure 1: Similarity between the pathological sequelae of Sepsis syndromes \& Sama sannipata jwara.

\section{Similarity between SSJ and Sepsis Syndromes}

The careful and in-depth study of SSJ lakshanas denotes an initial upper/lower respiratory tract infection which gradually converts in to pneumonia, which again leads to sepsis, SIRS, MODS, septic shock and ultimately to death in an individual with compromised immunity/low vitality/elderly (Figure 1). SSJ lakshnas contains the features of respiratory tract infections, pneumonia and sepsis.

\section{Features of Upper Respiratory Tract Infection/ Pneumonia in SSJ}

Lakshanas (signs \& symptoms) like, jwara, aruchi, kaasa, shwaasa, saasraave kalushe rakta lochane, srastaangata, asthi sandhi ruja, saswanau karnau, karna ruja, kantha shookairiva, kapha yukta rakta shteevana and pratatam kantha koojana denotes upper respiratory tract infection (bacterial/viral) and pneumonia. 'Kantha shookairiva' (feeling of thorns at throat) denotes acute inflammation of the pharynx, 'Mookatwa' (loss of voice) may be due to laryngitis (inflammation of larynx/voice box), 'Karna ruja' (pain in ear) and 'Karna swanau' (tinnitus) denotes 'Otitis media' (inflammation of the middle ear).

Infection with an influenza virus is commonly associated with a self limiting illness, usually manifesting as fever, malaise and cough. However, serious pneumonic infection may occur and this can become complicated by secondary bacterial infection. 'Streptococcal pharyngitis' is the most important of the bacterial infections of the pharynx due to 'group A beta-hemolytic 
streptococci'. Post infectious sequelae like abscess formation, acute rheumatic fever, post streptococcal glomerulo-nephritis are also common. Presence of conjunctivitis is the characteristic feature of 'Adenovirus pharyngitis' (pharyngo conjunctival fever). Acute laryngitis is mostly due to viral agents like, para-influenza virus, rhinovirus, influenza virus and adenovirus. Sore throat, fever, headache, nausea, vomiting, pharyngitis, tonsillitis, patchy discrete exudates etc; found in 'Streptococcus pyogenes' infection. Conjunctivitis, coryza, cough and diarrhea are due to viral etiology. [11] These features of respiratory tract infections (either bacterial or viral) like sore throat, fever, headache, nausea, pharyngitis, laryngitis, conjunctivitis, cough, malaise etc resemble with the lakshanas of SSJ like, 'kantha shookairiva', 'jwara', 'shiro ruja', 'aruchi', ' sroto paaka'/'kantha shookairiva,' 'mookatwa', 'saasraave kalushe rakta lochane', 'kaasa' and 'srastaangata' respectively.

The commonest bacteria which cause respiratory tract infections are pneumococci, Haemophilus influenzae, group a beta-hemolytic streptococci and Staphylococcus aureus [12]. Eustachian tube is more prone to blockage by hypertrophic lymphoid tissue of the proximal end due to respiratory tract infection. Otitis media (OM) infection is caused by Streptococcus pneumoniae and Hemophilus influenza commonly. Fever, local pain, secretory $\mathrm{OM}$ and impaired hearing are the most common features. Streptococcus pneumoniae infections are characterized by pluritic pain, fever, rusty sputum, cold sores; upper respiratory tract infection in young children and is often complicated by $\mathrm{OM}$ [13]. Pluritic pain, fever, conjunctivitis and rusty sputum denote, 'hridi vyatha', 'jwara,' 'saasraave kalushe ratka lochane' and 'kapha yukta rakta shteevana' of SSJ respectively. Features of pharyngitis, laryngitis, conjunctivitis and OM can be seen in SSJ lakshanas.

Mycoplasma pneumonia (MP) is an important infectious agent of the upper and lower respiratory tract and is endemic in most areas of the world. MP infection is a sub acute and gradual process, which usually lasts for a month or sometimes longer and it has a long latency period. The clinical symptoms of MP infection usually start in the upper respiratory tract and then gradually spread to the lower. Additionally liver damage, myocardial damage, anaemia, allergic purpura, nephritis, encephalitis etc may occur in MP infection [14]. These features like long latency period, liver damage/purpura, myocardial damage, nephritis and encephalitis of MP infection resembles with the lakshanas of SSJ like, chiraat paakashcha doshaanaam, shyava rakta kotha mandala darshanam, hridi vyatha, alpa mootra and shiraso lothana/bhrama/moha/ pralaapa/jwara respectively. Some of the SSJ lakshanas like aruchi, asthi sandhi ruja and shiro ruja denotes loss of appetite, arthralgia/myalgia and headache commonly found in various acute viral upper respiratory tract infections. By considering all these facts it is evident that SSJ lakshanas contains the features of conjunctivitis, pharyngitis, laryngitis and pneumonia (either due to bacterial or viral infection).

Pneumonia is the most frequent lung condition which leads to acute respiratory distress syndrome (ARDS). Virtually all patients with ARDS require mechanical ventilation. Pneumonia is the most frequent single cause of sepsis. Sepsis seems to be the principal link between pneumonia and ARDS. Corona virus and avian influenza virus are associated with an exceptionally high incidence of lung injury and ARDS [15]. Lakshanas of SSJ like 'pratatam kantha koojanam' and 'shwaasa' denotes ARDS and also acute lung injury (ALI).

\section{Features of Sepsis and SIRS in SSJ}

When the body is challenged by foreign microbial agents, homeostatic mechanisms come in to play which attempts to get rid from the foreign agent without damaging the host. This involves the activation of pro-inflammatory and anti-inflammatory pathways, which are highly controlled and regulated. In most of the individuals, the body is able to achieve a balance between pro-inflammatory and anti-inflammatory mediators and homeostasis is restored. But in some patients however this balance is upset with an excessive pro-inflammatory response resulting in SIRS, MODS, septic shock and ultimately death. There is compelling evidence that sepsis results from an exaggerated systemic inflammatory response induced by infecting organisms. Inflammatory mediators are the key players in the pathogenesis. Tissue hypoxia is an important factor leading to multi organ failure and death [16].

Sepsis is SIRS with evidence of an infection. Severe sepsis is sepsis associated with organ dysfunction, hypotension and hypoperfusion (lactic acidosis, oliguria \& altered mental status) [17]. The common early clinical manifestations seen in septic patients are fever, changes in mental status, tachypnea, tachycardia, hypotension, thrombocytopenia, coagulation abnormalities and leukocytosis. Significant edema (due to hypoxemia), decreased urine output (less than $0.5 \mathrm{ml} / \mathrm{kg} /$ hour), decreased platelet count (less than 100 000/micro litre) and mottling/decreased capillary refill are seen in sepsis [18]. In sepsis, generalized tissue edema develops as a rule due to fluid management under conditions of systemic capillary leak [19]. Adrenal insufficiency is also induced by sepsis by number of factors like vascular/ischemic damage/ inflammation/apoptosis within the hypothalamus pituitary adrenal axis [20]. These features of sepsis like edema, decreased urine output and thrombocytopenia/decreased platelet count resemble with 'naati krushatwam gaatraanaam', 'chiraat \& alpa mootra' and 'shyava rakta kotha mandala darshana' of SSJ respectively.

Sepsis is still a profoundly damaging and life threatening condition in many individuals. Diagnostic criteria for sepsis includes a documented or suspected pathogen plus two or more of the following SIRS abnormalities like, temperature greater than $38.5^{\circ} \mathrm{C}$ or less than $35^{\circ} \mathrm{C}$, heart rate above 90 beats/minute, respiratory rate greater than 20 breaths/minute and WBC (white blood corpuscles) count more than 12,000 cells $/ \mathrm{mm}^{3}$. Alterations in body temperature are frequently observed in experimental animals with sepsis. Fever is typically present in sepsis. Tachypnea in septic patients is due to an increased activation of the respiratory centre in the medulla by inflammatory mediators or as response to offset metabolic acidosis. Tachycardia is almost universally present and represents an important compensatory mechanism to maintain perfusion in response to intra vascular volume depletion, reduced cardiac contractility and vasodilation (dilated blood vessels) [21,22]. 
The characteristic features of sepsis like alteration in body temperature $\left(>38.5^{\circ} \mathrm{C}\right.$ or $\left.<35^{\circ} \mathrm{C}\right)$, tachycardia, tachypnea, fever, intra-vascular volume deficit, reduced cardiac contractility and vasodilation denotes the lakshanas like kshane daaha \& kshane sheeta, hridi vyatha, shwaasa/pratatam kantha koojanam, jwara, trishna/khara sparsha jihwa, bhrama/moha/hridi vyatha and naati krushatvam gaatraanaam (edema due to vasodilation?) of SSJ.

The human response to systemic infection and inflammation depends on the severity of disease, which ranges from sepsis to severe sepsis to septic shock with MODS. Clinical features vary depending on where a patient falls in that continuum (Figure 1). Some patients don't develop typical signs of sepsis such as fever and leukocytosis (increased WBC count). Failure to develop fever or the presence of hypothermia (temperature $<35.5^{\circ} \mathrm{C}$ ) is more common among non survivors of sepsis. Hypothermia is also associated with adverse outcomes in sepsis patients. Fever and hypothermia of sepsis denotes 'kshane daaha \& kshane sheeta' of SSJ. One of the lakshana of SSJ, 'sroto paaka' denotes active inflammation of channels or SIRS.

In conclusion with the evidence of an infection, a patient with SIRS would meet sepsis criteria. Severe sepsis is defined as sepsis with organ failure and septic shock as sepsis with hypotension which is refractory to volume resuscitation (ACCP). Fluid resuscitation is a cornerstone of severe sepsis treatment and should commence immediately after diagnosis of severe sepsis or septic shock [23]. The features of SSJ like 'trishna', 'khara sparsha jihwa', 'bhrama', 'chiraat and alpa sweda, mootra \& purisha' etc indicates intra-vascular volume deficit and need of fluid resuscitation.

\section{Features of Septic Shock/MODS in SSJ}

Severe sepsis occurs in the setting of hypo perfusion or organ dysfunction which may manifest physiologically as a sudden alteration in mental status or oliguria (which resembles with 'alpa mootra' of SSJ). In septic shock, hypotension (systolic blood pressure less than $90 \mathrm{~mm} \mathrm{hg}$ ) occurs in spite of adequate fluid resuscitation (denotes 'bhrama', 'moha', 'trishna', 'shiro ruja', 'alpa sweda \& mootra' and 'pralaapa' of SSJ). Every organ in the body may be damaged in the septic response and one of the recognized complications of sepsis is MODS. Acute kidney injury (AKI) in sepsis is due to acute tubular injury (ATI) (denotes 'chiraat and alpa mootra' of SSJ).

Cardio-vascular changes are also commonly seen in sepsis like tachycardia (hridi vyatha of SSJ), hypotension (bhrama of SSI) and reduced ejection fraction. Sepsis is also considered as the second most common cause of ALI and ARDS (denotes the features of SS) like shwaasa, pratatam kantha koojanam etc). Alveolar damage with edema and inactivation of surfactant cause collapse of alveoli and compromises pulmonary function. Interstitial fibrosis may also develop. In sepsis, hepatic injury is due to both extra and intra hepatic factors. Primary dysfunction is due to the decreased hepatic arterial blood flow from septic shock $[21,22]$.

DIC (Disseminated intra-vascular coagulation) in sepsis is characterized by systemic activation pro-coagulatory mechanisms, loss of anti-coagulant capability, and impaired fibrinolysis. DIC causes ischemic injury to various organs and leads to the development of multi organ failure. DIC is a dynamic process with consumption of platelets and coagulations factors which may leads to high risk of clinical bleeding [21,22] (which denotes shyava rakta kotha mandala darshana of SSJ). Most of the patients of sepsis develop coagulation abnormalities and the severity varies from mildly prolonged clotting times to fulminant overt DIC.

\section{Features of Septic Encephalopathy/Delirium in SSJ}

Sepsis associated encephalopathy occurs up to $87 \%$ of sepsis patients. Septic encephalopathy (SE) consists of alterations in mental status ranging from mild confusion to delirium/coma, poly neuropathy, with cognitive deficits, reduction in cerebral blood flow etc $[21,22]$. Agitation/delirium also found in sepsis [16]. SE is defined as brain dysfunction due to sepsis and SIRS and can also be called as sepsis-associated delirium. Acute impairment in the level of consciousness and confusion (manifested by alteration in attention, disorientation and concentration up to deep coma in more severe cases) are primarily defining symptoms. Symptoms like weakness, anorexia, malaise and concentration deficits which are commonly found in febrile patients [24]. Various features of SSJ like, 'tandra', 'moha', 'pralaapa', 'bhrama', 'shiraso lothanam', 'trishna', 'nidra naasha' and 'chiraat alpa sweda mootra purisha' etc resembles with SE or Delirium.

\section{Karna Moola Shotha (Swelling Behind the Ear) - Mastoiditis}

A swelling behind or below the ear/pinna develops during the terminal stages of sannipata jwara which is named as 'Karna moola shotha' and it will make the prognosis worst (only few people can survive with this swelling). The condition of 'Karna moola shotha' [25] resembles with 'Mastoiditis' which is the complication of $\mathrm{OM} /$ septicemia. Mastoiditis is an infection of the mastoid bone generally occurs subsequent to middle ear infection. As the disease progresses, post auricular erythema, swelling and tenderness develop. Swelling or tenderness behind the pinna should always be sought as mastoiditis which can be easily missed. There is normally a septicaemia with Hemophilus influenza. Clinically significant complications may occur like OM and sinusitis either due to viral origin or secondary bacterial super infection following common cold. Pain is the main symptom of OM. Acute otitis media (AOM) usually follows a viral infection. Congestion in the mucosa of eustachian tube leads to obstruction and stasis of middle ear secretions. Most common pathogens causing $\mathrm{OM}$ are Streptococcus pneumoniae, Hemophilus influenza, Moraxella catarrhalis and viruses. Complications may include mastoiditis and intra cranial spread of an infection. AOM is characterized by ear pain, fever, discharge, decreased hearing and irritability $[11,12]$.

\section{Conclusion}

All the incurable diseases are required to be explored in the purview of the pathology of sannipata. Sannipatika state is the complex phenomenon having intricate pathogenesis and 
justified intensive therapeutic care. Similarly sepsis causes substantial alterations which culminate in organ injury and high lethality. Complex and heterogeneous nature of sepsis challenges physicians and basic scientists. The incidence and mortality of severe sepsis and septic shock still remains very high which have decreased very little over the past decades. Regardless of the advance in the knowledge of sepsis and septic shock there is no 'magic bullet' to treat this syndrome. SSJ is one among 13 types of sannipata jwara which shows similarity with sepsis, SIRS, MODS, septic shock/septic encephalopathy and delirium. Karnamoola shotha which is the complication of sannipata jwara denotes a condition of mastoiditis leading to meningitis and death. There is profound similarity between SSJ and sepsis syndromes in terms of pathological progression, symptomatology and prognosis.

\section{References}

1. Panja AK, Chattopadhyaya A, Chaudhuri S (2011) A comprehensive outlook of sannipata. AYU 32 (2): 154-164.

2. Nishant K, Poonam B S, Yasmeen P, Hiremath (2011) Concept of gatavata from Ayurvedic perspective - A review article. International Ayurvedic Medical Journal 3(3): 862-868.

3. Talawar PD (2015) Avasthanurupa chikitsa in jwara and its role in clinical practice. Unique Journal of Ayurvedic and Herbal medicines 3(94): 109-111.

4. Nagaraj S, Nidhin V (2015) A study on vishama jwara nidaana with special reference to risk factors in malarial fever. International Ayurvedic Medical Journal 3(8): 2318-2325.

5. Seethadevi P, Sharma VS (2016) Understanding of taruna jwara chikitsa sootra. World Journal of Pharmacy and Pharmaceutical Sciences 5(7): 576-583.

6. Srivastava S (2015) An Ayurvedic insight towards Dengue fevers. European Journal of Pharmaceutical and Medical Research 2(4): 693-698.

7. Kulkarni M A (2016) Comparison of the types of jwara in MSS 'Bhishak chakra chittotsava' with brihat trayi and laghu trayi. International Ayurvedic Medical Journal 4(3): 377-381.

8. Mahadev PM, Kaveri H, Tonne V, Mishra D (2015) Stills disease versus sama sannipataja jwara: A hypothetical review. International Journal of Technical Research and Applications 4(2): 45-49.

9. Rajan PR, Satyendrakumar SRP (2012) Comparative study of vikriti vishama samavayarabdha sannipatika jwara described in charka with reference to dengue fever. International Journal of Research in Ayurveda and Pharmacy 3(4): 528-531.

10. Madhavakara (2012) Madhava nidaana with Sanskrit commentary 'Madhukosha' by Vijayarakshita and Shrikanthadatta. Vol 1. Jwara nidaana adhyaya, 2 / 18-23. In: Dr Brahmananda Tripathi \& Chaukhamba surbharati prakashan (Eds.), Varanasi, India, pp. 111120.
11. Barton E, Spencer R (2017) URTIs recommended diagnosis and treatment in general practice.

12. Valman HB (1980) Respiratory infections in the older infant. British Medical Journal 281(6234): 1438-1442.

13. Chonmaitree T, Revai K, Grady JJ, Clos A, Patel JA, et al. (20098) Viral upper respiratory tract infection and otitis media complication in young children. Clin Infect Dis 46(6): 815-823.

14. Zhai SB, Cao DB, Xu H, Li XX, Yang SR (2012) Multiple organ dysfunction syndrome associated with Mycoplasma pneumonia infection. Braz J Microbiol 43(1): 230-234.

15. Bauer TT, Ewig S, Rodloff AC, Muller EE (2006) Acute respiratory distress syndrome and pneumonia: A comprehensive review of clinical data. Clin Infect Dis 43(6): 748-756.

16. Kasai T, Inada K, Takakuwa T, Yamada Y, Inoue Y, et al. (1997) Antiinflammatory cytokine levels in patients with septic shock. Res Commun Mol Pathol Pharmacol 98(1): 34-42.

17. Razvi SS, Bone I (2003) Neurological consultations in the medical intensive care unit. J Neurol Neurosurg Psychiatry 74(suppl III): iii 16- iii 23.

18. Balk RA (2014) Systemic inflammatory response syndrome (SIRS): where did it come from and is it still relevant today? Virulence 5(1): 20-26.

19. Manak J, Schreiber M, Matulova H, Slemrova M, Cerman J, et al. (2003) Does generalized edema in sepsis increase muscular tissue pressure? Crit Care 7(suppl 2): P052.

20. Annane D (2008) Adrenal insufficiency in sepsis. Curr Pharm Des 14(19): $1882-1886$.

21. Iskander KN, Osuchowski MF, Stearns-Kurosawa DJ, Kurosawa S, Stepien D, etal. (2013) Sepsis: multiple abnormalities, heterogeneous responses, and evolving understanding. Phyiol Rev 93(3): 12471288.

22. Pinsky MR, Vincent JL, Deviere J, Alegre M, Kahn RJ, et al. (1993) Serum cytokine levels in human septic shock: Relation to multiple system organ failure and mortality. Chest 103(2): 565-575.

23. Finfer S, Bellomo R, Boyce N, French J, Myburgh J, et al. (2004) A comparison of albumin and saline for fluid resuscitation in the intensive care unit. N Engl J Med 350(22): 2247-2256.

24. Ringer TM, Axer H, Romeike BFM, Zinke J, Brunkhorst F, et al. (2011) Neurological sequelae of sepsis: I) Septic encephalopathy. Open Crit Care Med J 4: 2-7.

25. Madhavakara (2012) Madhava nidaana with Sanskrit commentary 'Madhukosha' by Vijayarakshita and Shrikanthadatta. Vol 1. Jwara nidaana adhyaya, 2 / 25. In: Dr Brahmananda Tripathi \& Chaukhamba surbharati prakashan (Eds.), Varanasi, India, p. 122. 